\title{
Successful full-term delivery in a patient with maintenance hemodialysis using natriuretic peptides as volume markers without X-ray examination: a case report and literature review
}

\author{
Naomi Matsuo, Yushi Nakayama, Hideki Inoue, Yuichiro Izumi io and Masashi Mukoyama
}

\begin{abstract}
A 38-year-old female undergoing maintenance hemodialysis became pregnant. To avoid X-ray exposure, plasma levels of natriuretic peptides were mainly used to determine dry weight. Dry weight was increased every week according to the gestation week. By closely monitoring the levels of natriuretic peptides, blood pressure, and amniotic fluid volume, general conditions remained stable. At 37 weeks of gestation, she delivered a healthy girl with an appropriate-for-date birth weight. We propose the measurement of natriuretic peptides as useful for managing volume during pregnancy without $X$-ray exposure. Future studies are required to explore the regulation and monitoring of hydration status during pregnancy.
\end{abstract}

Keywords: Hemodialysis Pregnancy Dry weight Natriuretic peptide X-ray

\section{Background}

Through the technical advancement of dialysis therapy, long-term prognosis and quality of life in patients with end-stage renal failure have drastically improved in recent decades. The average age of dialysis initiation has also been increasing year after year. However, many young females require chronic dialysis therapy; therefore, nephrologists are challenged by the important issue of pregnancy in such patients. In general, successful pregnancy is uncommon in dialysis patients. After the first report of successful delivery in 1971 [1], a number of case reports and reviews have been published about pregnancy and delivery in patients on dialysis [2-7]. Holley and Reddy suggested the ideal condition of hemodialysis for having a healthy child [8]. However, there are still many problems that hinder successful fullterm pregnancy in patients on dialysis, partly due to complications including spontaneous miscarriage, premature delivery, intrauterine growth inhibition, polyhydramnios, and pregnancy-induced hypertension [8].

* Correspondence: izumi_yu@kumamoto-u.ac.jp

Department of Nephrology, Kumamoto University Graduate School of Medical Sciences, 1-1-1 Honjo, Chuo-ku, Kumamoto 860-8556, Japan
One of the important issues is the determination of dry weight (DW), which should be changed according to fetal growth. In nonpregnant patients, the cardiothoracic ratio obtained by X-ray photography is used together with the blood pressure (BP) and edematous condition to determine the ideal DW. Recently, the plasma levels of atrial and brain natriuretic peptides (ANP and BNP) have been recognized as useful markers for not only the assessment of cardiovascular risk but also the determination of the appropriate extracellular fluid volume status [9-11]. X-ray exposure is not preferable for pregnant women especially during the early pregnancy period. Furthermore, most Japanese people became extremely concerned about radiation after the serious accident that occurred at the Fukushima Daiichi Nuclear Power Plant. This report describes a successful pregnancy and fullterm delivery of an infant in a dialysis patient using mainly ANP and BNP, instead of X-ray examination, to determine DW.

\section{Case presentation}

A 38-year-old female receiving maintenance hemodialysis was referred to our hospital for control during pregnancy. 
She was diagnosed with IgA nephropathy by renal biopsy at 20 years of age. At ages 26 and 29, she delivered full-term infants with normal birth weights without complications. Then, she discontinued attending the hospital regularly and her renal function deteriorated with time. Four years later, hemodialysis was initiated in our hospital due to uremia. When hospitalized, she was diagnosed as having heparininduced thrombocytopenia type II (HIT type II); at this time, nafamostat mesilate was chosen as an anticoagulant agent. After discharge, she continued maintenance hemodialysis at a satellite facility during which time her case remained uneventful. Five years later, she was diagnosed as 5 -week pregnant at the maternity division in our hospital. She was referred to our division for the maintenance of dialysis therapy.

Blood data before dialysis and echocardiographic findings after dialysis are shown in Table 1 . Hemoglobin $(\mathrm{Hb})$ and electrolyte levels were well controlled, but the intact parathyroid hormone (iPTH) level was high. The blood urea nitrogen (BUN) concentration was below $50 \mathrm{mg} / \mathrm{dL}$. The postdialysis ANP level was slightly high, but the BNP level was maintained low. Slight pericardial effusion was observed, but cardiac function was well preserved. According to previous reports on management guidance $[8,12]$, we performed sufficient dialysis over $20 \mathrm{~h} /$ week. Because she had HIT, nafamostat mesilate was used as an anticoagulant agent.

The changes in the patient's body weight (BW) and BP are shown in Fig. 1. DW started to increase after the 12th week of gestation by $0.3-0.5 \mathrm{~kg} /$ week, in accordance with the guide and from recommendations by obstetricians of our hospital. Weight gain between each dialysis session remained almost stable, within a 5\% DW increase between each session. For determining the ideal DW, we measured the plasma levels of ANP and BNP (Fig. 1) rather than performing the X-ray examination to avoid radiation exposure. Echocardiographic data were also followed each month after the last dialysis session of the week to evaluate the diameter of inferior vena cava (IVC), as well as cardiac function. During the observation period, cardiac function remained normal and well preserved. Measurement of the IVC diameter was considered useful at an early stage of pregnancy. At a later stage of pregnancy, however, the IVC became collapsed even before the dialysis session due to the fetal growth, making it difficult to evaluate body fluid status echocardiographically. Target BUN and $\mathrm{Hb}$ levels before the dialysis session were below $50 \mathrm{mg} / \mathrm{dL}$ and over $10 \mathrm{~g} /$ $\mathrm{dL}$, respectively. The hemodialysis dose was increased to 4 times/week after 7 weeks of gestation and was further increased to 5 times/week after 26 weeks of gestation.

Table 1 Physical findings and laboratory data upon admission

\begin{tabular}{|c|c|c|c|c|c|}
\hline \multicolumn{2}{|l|}{ Physical findings } & \multicolumn{4}{|c|}{ Blood chemistry } \\
\hline Height & $165.0 \mathrm{~cm}$ & TP & $6.8 \mathrm{~g} / \mathrm{dL}$ & $\mathrm{HbA1c}$ & $5.3 \%$ \\
\hline \multirow[t]{3}{*}{ Body weight } & $49.0 \mathrm{~kg}(\mathrm{DW})$ & Alb & $4.2 \mathrm{~g} / \mathrm{dL}$ & PT & $11.7 \mathrm{~s}$ \\
\hline & & $\mathrm{Na}$ & 134 mEq/L & APTT & $33.1 \mathrm{~s}$ \\
\hline & & K & $4.6 \mathrm{mEq} / \mathrm{L}$ & BNP (pre-HD) & $49 \mathrm{pg} / \mathrm{mL}$ \\
\hline \multirow[t]{2}{*}{ Blood pressure } & 144/91 mmHg & $\mathrm{Cl}$ & $98 \mathrm{mEq} / \mathrm{L}$ & & \\
\hline & & $\mathrm{Ca}$ & $9.6 \mathrm{mg} / \mathrm{dL}$ & ANP (post-HD) & $102 \mathrm{pg} / \mathrm{mL}$ \\
\hline \multirow[t]{5}{*}{ Pulse rate } & 70/min & $P$ & $5.4 \mathrm{mg} / \mathrm{dL}$ & & \\
\hline & & UA & $4.8 \mathrm{mg} / \mathrm{dL}$ & Intact PTH & $398 \mathrm{pg} / \mathrm{mL}$ \\
\hline & & BUN & $42 \mathrm{mg} / \mathrm{dL}$ & & \\
\hline & & $\mathrm{Cr}$ & $8.4 \mathrm{mg} / \mathrm{dL}$ & & \\
\hline & & T-Bil & $0.3 \mathrm{mg} / \mathrm{dL}$ & & \\
\hline \multicolumn{2}{|l|}{ Complete blood count } & AST & $9 \mathrm{U} / \mathrm{L}$ & Echocardiography & \\
\hline WBC & $4900 / \mu \mathrm{L}$ & ALT & $5 \mathrm{U} / \mathrm{L}$ & EF & $66 \%$ \\
\hline RBC & $4.06 \times 10^{6} / \mu \mathrm{L}$ & LDH & $115 \mathrm{U} / \mathrm{L}$ & LVDd & $44.3 \mathrm{~mm}$ \\
\hline \multirow[t]{3}{*}{ Hemoglobin } & $11.0 \mathrm{~g} / \mathrm{dL}$ & Y-GTP & $26 \mathrm{U} / \mathrm{L}$ & LVDs & $25.1 \mathrm{~mm}$ \\
\hline & & & & IVSTd & $9.0 \mathrm{~mm}$ \\
\hline & & ALP & $170 \mathrm{U} / \mathrm{L}$ & $\% F S$ & $41.5 \%$ \\
\hline Hematocrit & $34.2 \%$ & CK & $48 \mathrm{U} / \mathrm{L}$ & $\mathrm{CO}$ & $4.1 \mathrm{~L} / \mathrm{min}$ \\
\hline \multirow[t]{3}{*}{ Platelet } & $144 \times 10^{3} / \mu \mathrm{L}$ & Glucose & $111 \mathrm{mg} / \mathrm{dL}$ & IVC insp/exp & $9.9 / 20.2 \mathrm{~mm}$ \\
\hline & & & & Pericardial fluid & $(+-)$ \\
\hline & & & & Asynergy & $(-)$ \\
\hline
\end{tabular}




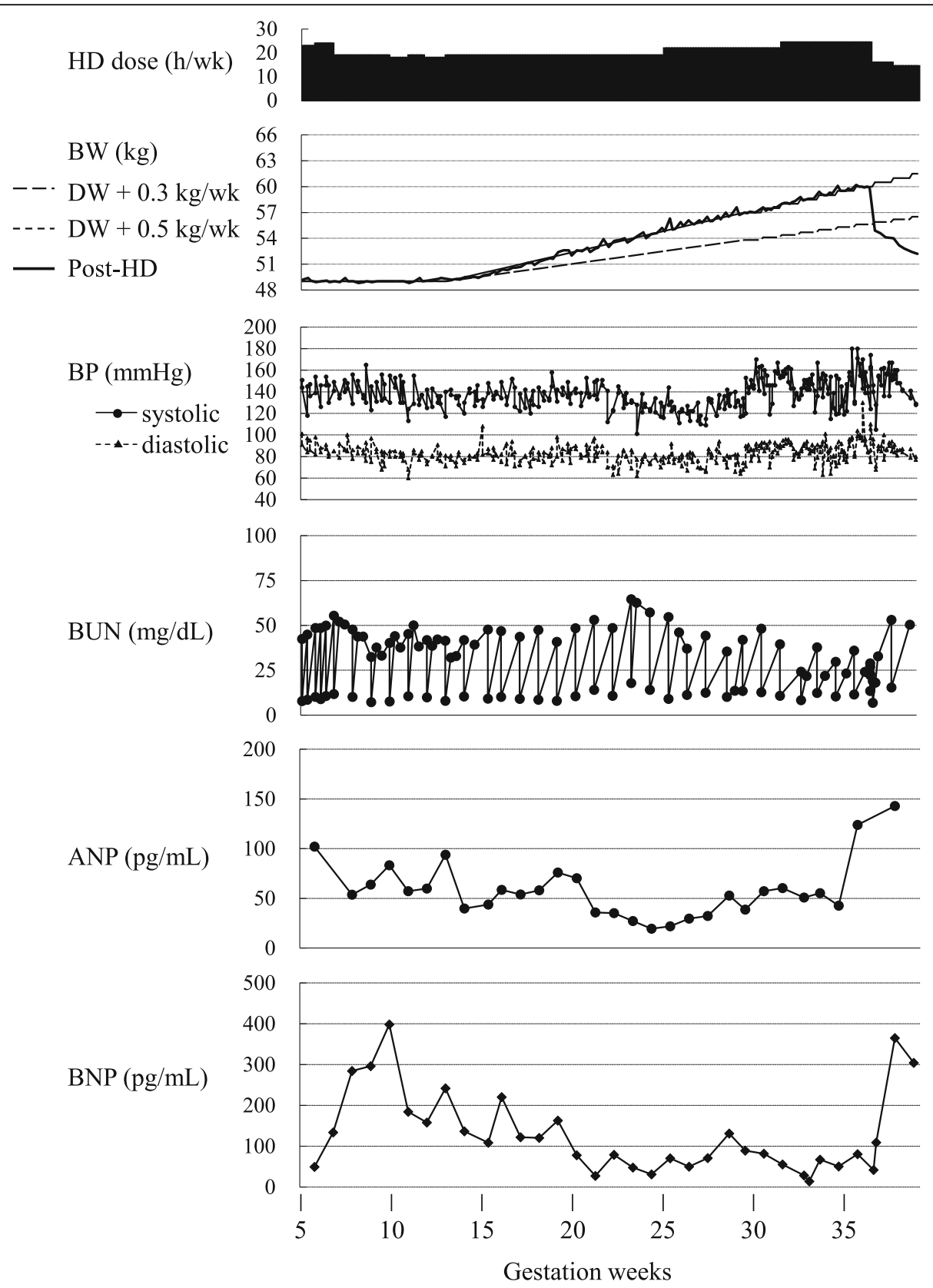

Fig. 1 Clinical course of the patient during pregnancy. HD, hemodialysis; BW, body weight; DW, dry weight; BP, blood pressure; BUN, blood urea nitrogen; ANP, atrial natriuretic peptide; BNP, brain natriuretic peptide

At 29 weeks of gestation, the patient suffered from impending preterm delivery and was admitted to our hospital for the remainder of her pregnancy. She started to receive $50 \mu \mathrm{g} / \mathrm{kg} / \mathrm{min}$ of ritodrine hydrochloride. Because her weight gain between dialysis sessions became larger and the BUN levels tended to increase, the hemodialysis dose was increased to 6 days/week ( $4.5 \mathrm{~h} /$ session) starting at 31 weeks of gestation. Thereafter, the BUN levels remained mostly below $50 \mathrm{mg} / \mathrm{dL}$ until full-term (Fig. 1). During the gestation period, the single-pool Kt/V ranged from 1.3 to 2.2 (average, $1.8 \pm 0.05$ ). The $\mathrm{Hb}$ levels were maintained between 10 and $12 \mathrm{~g} / \mathrm{dL}$ with the administration of an erythropoietin analog and iron. Calcium, phosphate, and PTH levels were controlled within recommended ranges throughout the course with vitamin $\mathrm{D}$ and phosphate-binding agents.

During the dialysis session, the BP levels were targeted to remain below 140/90 $\mathrm{mmHg}$ with minimal BP fluctuations. After being referred to our hospital, oral administration of 
$750 \mathrm{mg} / \mathrm{d}$ methyldopa hydrate was started. Nifedipine controlled-release (CR) was used up to $80 \mathrm{mg} / \mathrm{d}$ from 31 gestation weeks for the gradual increase in BP. The ANP and BNP levels remained almost stable despite BW increases near the delivery date (Fig. 1).

At 37 weeks of gestation, she had genital bleeding and underwent emergency cesarean section. After a 45 -min surgery, she delivered a $2372 \mathrm{~g}$ (-0.6SD) healthy girl who had an appropriate-for-date birth weight. Apgar scores were 8 and 9 at 1 and $5 \mathrm{~min}$, respectively. After the delivery, the patient returned to regular hemodialysis (3 times/week) without peripartum complications and was discharged with her baby 10 days after delivery.

\section{Discussion and conclusions}

In dialysis patients, the chance of pregnancy is rare, partly due to anovulation, hyperprolactinemia, and decreased libido caused by altered human chorionic gonadotropin pulses and reduced renal leptin clearance [13]. The registry revealed that only $2 \%$ of women on chronic dialysis became pregnant over a 4-year period [14]. Levy et al. proposed the management guide to optimize pregnancy outcomes in dialysis patients [12]. First, the dialysis dose must be increased to keep the levels of uremic toxins low. Second, the BP should be stabilized for maintaining stable placental circulation. Most importantly, DW should be increased carefully according to the gestation week and fetal growth. Many

Table 2 Case reports on delivery with maintenance hemodialysis or peritoneal dialysis

\begin{tabular}{|c|c|c|c|c|c|c|c|c|c|c|}
\hline Authors & Year & $\begin{array}{l}\text { Age at } \\
\text { conception }\end{array}$ & $\begin{array}{l}\text { Duration of HD } \\
\text { or PD }\end{array}$ & $\begin{array}{l}\text { Pregnancy- } \\
\text { confirmed } \\
\text { GA }\end{array}$ & $\begin{array}{l}\text { Intensive } \\
\text { dialysis }\end{array}$ & $\begin{array}{l}\text { Dry weight } \\
\text { gained }\end{array}$ & $\begin{array}{l}\text { GA at } \\
\text { birth } \\
\text { (weeks } \\
+ \text { days) }\end{array}$ & $\begin{array}{l}\text { Weight } \\
\text { of birth }\end{array}$ & $\begin{array}{l}\text { Pregnancy- } \\
\text { related } \\
\text { complications } \\
\text { in patient }\end{array}$ & $\begin{array}{l}\text { Complications } \\
\text { in neonate }\end{array}$ \\
\hline $\begin{array}{l}\text { Matsuo et } \\
\text { al. (present } \\
\text { report) }\end{array}$ & 2019 & $\begin{array}{l}38 \text { years } \\
\text { old }\end{array}$ & 1-year HD & $5 \mathrm{GA}$ & $\begin{array}{l}4-6 \text { sessions } \\
\text { (> } 20 \mathrm{~h} \text { in } \\
\text { total) per } \\
\text { week }\end{array}$ & $\begin{array}{l}0.3-0.5 \mathrm{~kg} / \\
\text { week, } \\
\text { measurement } \\
\text { of ANP and } \\
\text { BNP }\end{array}$ & 37 & $2372 \mathrm{~g}$ & Hypertension & LBW \\
\hline $\begin{array}{l}\text { Cao et al. } \\
{[23]}\end{array}$ & 2018 & $\begin{array}{l}34 \text { years } \\
\text { old }\end{array}$ & 4-year HD & $16 \mathrm{GA}$ & $\begin{array}{l}20 \mathrm{~h} \text { per } \\
\text { week }\end{array}$ & $0.5 \mathrm{~kg} /$ week & $31+4$ & $1700 \mathrm{~g}$ & $\begin{array}{l}\text { Hypertension, } \\
\text { polyhydramnios }\end{array}$ & $\begin{array}{l}\text { Prematurity, } \\
\text { LBW }\end{array}$ \\
\hline $\begin{array}{l}\text { Choi et al. } \\
{[24]}\end{array}$ & 2018 & $\begin{array}{l}37 \text { years } \\
\text { old }\end{array}$ & 1-year PD & $7 \mathrm{GA}$ & $\begin{array}{l}\text { Five } 2-\mathrm{L} \text { ex- } \\
\text { changes per } \\
\text { day }\end{array}$ & No description & $27+4$ & $1060 \mathrm{~g}$ & & $\begin{array}{l}\text { Prematurity, } \\
\text { VLBW }\end{array}$ \\
\hline $\begin{array}{l}\text { Akbari et } \\
\text { al. [25] }\end{array}$ & 2016 & $\begin{array}{l}33 \text { years } \\
\text { old }\end{array}$ & $\begin{array}{l}\text { 8-year kidney } \\
\text { transplant and } \\
\text { then 3-month } \\
\text { HD }\end{array}$ & $6 \mathrm{GA}$ & $\begin{array}{l}\text { Six sessions } \\
\text { ( } 45 \mathrm{~h} \text { in } \\
\text { total) per } \\
\text { week }\end{array}$ & No description & 35 & $2012 \mathrm{~g}$ & Hypertension & LBW \\
\hline \multirow[t]{4}{*}{$\begin{array}{l}\text { Chang et } \\
\text { al. [26] }\end{array}$} & 2016 & $\begin{array}{l}38 \text { years } \\
\text { old }\end{array}$ & 5-year HD & $20 \mathrm{GA}$ & $\begin{array}{l}\text { Five sessions } \\
\text { ( } 20 \mathrm{~h} \text { in } \\
\text { total) per } \\
\text { week }\end{array}$ & 0.12 kg/week & $36+5$ & $2460 \mathrm{~g}$ & & LBW \\
\hline & & $\begin{array}{l}40 \text { years } \\
\text { old }\end{array}$ & 8.3-year HD & $12 \mathrm{GA}$ & $\begin{array}{l}\text { Six sessions } \\
(24 \mathrm{~h} \text { in } \\
\text { total) per } \\
\text { week }\end{array}$ & 0.21 kg/week & $29+3$ & $1252 \mathrm{~g}$ & PE, PROM & $\begin{array}{l}\text { Prematurity, } \\
\text { VLBW }\end{array}$ \\
\hline & & $\begin{array}{l}32 \text { years } \\
\text { old }\end{array}$ & 8-year HD & $6 \mathrm{GA}$ & $\begin{array}{l}\text { Six sessions } \\
(24 \mathrm{~h} \text { in } \\
\text { total) per } \\
\text { week }\end{array}$ & 0.37 kg/week & $27+3$ & $1090 \mathrm{~g}$ & $\begin{array}{l}\text { PE, } \\
\text { polyhydramnios }\end{array}$ & $\begin{array}{l}\text { Prematurity, } \\
\text { VLBW }\end{array}$ \\
\hline & & $\begin{array}{l}37 \text { years } \\
\text { old }\end{array}$ & 2-year HD & $18 \mathrm{GA}$ & $\begin{array}{l}\text { Three } \\
\text { sessions ( } 12 \\
\mathrm{~h} \text { in total) } \\
\text { per week }\end{array}$ & 0.28 kg/week & $37+3$ & $2330 \mathrm{~g}$ & & LBW \\
\hline $\begin{array}{l}\text { Yu et al. } \\
{[27]}\end{array}$ & 2015 & $\begin{array}{l}22 \text { years } \\
\text { old }\end{array}$ & 6-year HD & $22 \mathrm{GA}$ & Daily 4-h HD & No description & $34+4$ & $1470 \mathrm{~g}$ & Polyhydramnios & VLBW \\
\hline $\begin{array}{l}\text { Jung et al. } \\
\text { [28] }\end{array}$ & 2014 & $\begin{array}{l}38 \text { years } \\
\text { old }\end{array}$ & 3-year HD & $8 \mathrm{GA}$ & $\begin{array}{l}\text { 4-5 sessions } \\
\text { 4-h HD per } \\
\text { week }\end{array}$ & $0.5 \mathrm{~kg} /$ week & 34.5 & $2100 \mathrm{~g}$ & $\begin{array}{l}\text { Postpartum } \\
\text { cardiomyopathy }\end{array}$ & LBW \\
\hline $\begin{array}{l}\text { Thompson } \\
\text { et al. [29] }\end{array}$ & 2011 & $\begin{array}{l}30 \text { years } \\
\text { old }\end{array}$ & $\begin{array}{l}\text { None, initiated } \\
\text { at } 9 \mathrm{GA}\end{array}$ & $7 \mathrm{GA}$ & $\begin{array}{l}\text { Six sessions } \\
6-h \text { HD per } \\
\text { week }\end{array}$ & 0.45 kg/week & 39 & $3000 \mathrm{~g}$ & & \\
\hline
\end{tabular}

RRT renal replacement therapy, GA gestational age, $P E$ preeclampsia, $H T$ hypertension, $L B W$ low birth weight, VLBW very low birth weight, $C$-section cesarean section 
evaluations such as the edematous condition, BP levels, $\mathrm{X}$-ray exam, Crit-Line measurement, IVC diameter, and plasma ANP or BNP levels are usually employed to determine the ideal DW. Among them, we decided to use mainly the ANP and BNP levels, along with the edematous condition, BP, and IVC diameter to avoid X-ray exposure.

Increases in ANP and BNP, cardiac hormones secreted predominantly from the atria and ventricles, respectively, are well known to be increased in congestive heart failure [15-18]. However, plasma levels of these peptides are also elevated in patients undergoing dialysis in response to hypervolemia, as well as latent or overt ventricular dysfunction [19]. In our case, we mainly used the plasma levels of ANP and BNP to control appropriate hydration status and evaluate cardiac function. Eventually, these peptide levels remained stable throughout the gestation period, and BP and amniotic fluid volume were kept quite stable until the full-term delivery of a healthy baby. We used an X-ray exam only once at a stable period (29th gestation week; CTR 46.0\%). There are a few clinical studies regarding delivery in patients on hemodialysis. A retrospective, multicentric study consisting of 100 pregnancies in patients on hemodialysis from 1985 to 2015 in France revealed a mean gestational age of $33.2 \pm 3.9$ weeks and a mean birth weight of 1719 $\pm 730 \mathrm{~g}[20]$. Another retrospective cohort study consisting of 93 pregnancies in patients on hemodialysis from 2000 to 2017 in Brazil revealed a median gestational age of 35 (12-39) and a mean birth weight of $1698 \pm 719$ g; in addition, preeclampsia, primigravida, average midweek BUN, polyhydramnios, and residual diuresis were associated with birth weight [21]. In a nationwide survey on pregnancy in patients with end-stage renal disease carried out in Japan, neonates who died were younger in gestational age (26.2 weeks) with lower birth weight, and all infants who died were born less than $1000 \mathrm{~g}$ [22]. These authors concluded that premature delivery is a major problem in patients on chronic dialysis in spite of the improved rate of pregnancy, impeding successful outcomes without complications. As case reports have reported for the last several years (Table 2), premature delivery is still a problem that should be considered. To this end, the present case suggests that strict volume control is crucial. Thus, we propose monitoring plasma ANP and BNP levels as a useful strategy for managing volume during pregnancy and achieving successful fullterm delivery. In addition, rigorous managements of anemia and mineral and bone disorder, which are inevitable complications in dialysis patients, also should be considered to keep pregnancy in good condition and to reach full-term delivery.

Future studies are required to further explore the regulation and monitoring of hydration status and the best management in dialysis patients during pregnancy for a successful and safe delivery. In our case, ANP and BNP levels were stable and relatively low, reflecting good control of hydration status. Stability of ANP and BNP levels could lead to full-term delivery. Appropriate ranges of ANP and BNP need to be examined.

\section{Acknowledgements}

Not applicable.

\section{Authors' contributions \\ NM and YI wrote the manuscript. HI, YN, and MM contributed to the treatment of the patient and discussed and reviewed the manuscript. All authors read and approved the final version of the manuscript.}

\section{Authors' information}

MN is a graduate student in the Department of Nephrology at Kumamoto University Graduate School of Medical Sciences. YN and YI are a lecturer and an assistant professor, respectively, in the Department of Nephrology at Kumamoto University Graduate School of Medical Sciences. HI is an associate professor of Kumamoto University Hospital. MM is a chief professor in the Department of Nephrology at Kumamoto University Graduate School of Medical Sciences.

\section{Funding}

This work was not supported by any funding.

Availability of data and materials

All of the data and materials are included in the manuscript.

\section{Ethics approval and consent to participate}

This case report was written in compliance with the Declaration of Helsinki and approved by the Ethical Committee of Kumamoto University Graduate School of Medical Sciences (No. 1618).

\section{Consent for publication}

Because the patient died with lung cancer in November 5, 2015, authors needed to obtain the consent from her family. However, the authors could not make contact with any family members by any means after her death. For this reason, the research ethics committee of Kumamoto University Graduate School of Medical Sciences approved the submission of our case report (No. 1618).

\section{Competing interests}

The authors declare that they have no competing interests.

Received: 27 December 2018 Accepted: 18 July 2019

Published online: 13 August 2019

\section{References}

1. Confortini P, Galanti G, Ancona G, Giongio A, Bruschi E, Lorenzini E. Full-term pregnancy and successful delivery in a patient on chronic hemodialysis. Proc Eur Dial Transplant Assoc. 1971:8:74-80.

2. Hou SH. Frequency and outcome of pregnancy in women on dialysis. Am J Kidney Dis. 1994;23:60-3.

3. Chan WS, Okun N, Kjellstrand CM. Pregnancy in chronic dialysis: a review and analysis of the literature. Int J Artif Organs. 1998:21:259-68.

4. Luciani G, Bossola M, Tazza L, Panocchia N, Liberatori M, De Carolis S, Piccioni E, De Carolis MP, Caruso A, Castagneto M. Pregnancy during chronic hemodialysis: a single dialysis-unit experience with five cases. Ren Fail. 2002;24:853-62.

5. Pipili C, Grapsa E, Koutsobasili A, Sorvinou P, Poirazlar E, Kiosses D, Xatzigeorgiou G. Pregnancy in dialysis-dependent women--the importance of frequent dialysis and collaborative care: a case report. Hemodial Int. 2011;15:306-11.

6. Piccoli GB, Conijn A, Consiglio V, Vasario E, Attini R, Deagostini MC, Bontempo S, Todros T. Pregnancy in dialysis patients: is the evidence strong enough to lead us to change our counseling policy? Clin J Am Soc Nephrol. 2010;5:62-71. 
7. Gadallah MF, Ahmad B, Karubian F, Campese VM. Pregnancy in patients on chronic ambulatory peritoneal dialysis. Am J Kidney Dis. 1992;20:407-10.

8. Holley JL, Reddy SS. Pregnancy in dialysis patients: a review of outcomes, complications, and management. Semin Dial. 2003;16:384-8.

9. Joffy S, Rosner MH. Natriuretic peptides in ESRD. Am J Kidney Dis. 2005;46:1-10.

10. Dastoor H, Bernieh B, Boobes Y, Abouchacra S, Eltayeb E, Elhuda MN, Kazzam E, Obineche EN, Nicholls MG. Plasma BNP in patients on maintenance haemodialysis: a guide to management? J Hypertens. 2005;23:23-8.

11. Wang AY. Clinical utility of natriuretic peptides in dialysis patients. Semin Dial. 2012;25:326-33.

12. Levy DP, Giatras I, Jungers P. Pregnancy and end stage renal disease: past experience and new insights. Nephrol Dial Transplant. 1998;13:3005-7.

13. Merabet E, Dagogo-Jack S, Coyne DW, Klein S, Santiago JV, Hmiel SP, Landt M. Increased plasma leptin concentration in end stage renal disease. J Clin Endocrinol Metab. 1997:82:847-50.

14. Okundaye I, Abrinko P, Hou S. Registry of pregnancy in dialysis patients. Am J Kidney Dis. 1998;31:766-73.

15. Burnett JC Jr, Kao PC, Hu DC, Heser DW, Heublein D, Granger JP, Opgenorth TJ, Reeder GS. Atrial natriuretic peptide elevation in congestive heart failure in the human. Science. 1986;231:1145-7.

16. Mukoyama M, Nakao K, Saito Y, Ogawa Y, Hosoda K, Suga S, Shirakami G, Jougasaki $\mathrm{M}$, Imura $\mathrm{H}$. Increased human brain natriuretic peptide in congestive heart failure. N Engl J Med. 1990;323:757-8,

17. Mukoyama M, Nakao K, Hosoda K, Suga S, Saito Y, Ogawa Y, Shirakami G, Jougasaki M, Obata K, Yasue H. Brain natriuretic peptide as a novel cardiac hormone in humans. Evidence for an exquisite dual natriuretic peptide system, atrial natriuretic peptide and brain natriuretic peptide. J Clin Invest. 1991;87:1402-12.

18. Ruskoaho H. Cardiac hormones as diagnostic tools in heart failure. Endocr Rev. 2003;24:341-56.

19. Nishikimi T, Futoo Y, Tamano K, Takahashi M, Suzuki T, Minami J, Honda T, Uetake S, Asakawa H, Kobayashi N, Horinaka S, Ishimitsu T, Matsuoka H. Plasma brain natriuretic peptide levels in chronic hemodialysis patients: influence of coronary artery disease. Am J Kidney Dis. 2001;37:1201-8.

20. Normand G, Xu X, Panaye M, Jolivot A, Lemoine S, Guebre-Egziabher F, Decullier E, Bin S, Doret M, Julillard L. Pregnancy outcomes in French hemodialysis patients. Am J Nephrol. 2018:47:219-27.

21. Luders C, Titan SM, Kahhale S, Francisco RP, Zugaib M. Risk factors for adverse fetal outcome in hemodialysis pregnant women. Kidney International Reports. 2018;3:1077-88.

22. Toma H, Tanabe K, Tokumoto T, Kobayashi C, Yagisawa T. Pregnancy in women receiving renal dialysis or transplantation in Japan: a nationwide survey. Nephrol Dial Transplant. 1999;14:1511-6.

23. Cao Y, Zhang Y, Wang X, Zhang Y, Fan Y, Shi H, Dai H. Successful pregnancy and delivery in uremic patients with maintenance hemodialysis. A case report. Medicine. 2018:50(e13614):97.

24. Choi CY, Cho NJ, Park S, Gil HW, Kim YS, Lee EY. A case report of successful pregnancy and delivery after peritoneal dialysis in a patient misdiagnosed with primary infertility. Medicine. 2018;26e(e11148):97.

25. Akbari A, Hladunewich M, Burns K, Moretti F, Arkoub RA, Brown P, Hiremath S. Circulating angionenic factors in a pregnant woman on intensive hemodialysis: a case report. Can J Kidney Health Dis. 2016;3:7.

26. Chang JY, Jang H, Chung BH, Youn YA, Sung IK, Kim YS, Yang CW. The successful clinical outcomes of pregnant women with advanced chronic kidney disease. Kidney Res Clin Pract. 2016:84-9.

27. Yu P, Diao W, Tang Q, Jiang X. A successful pregnancy and parturition in a patient with anuria undergoing maintenance hemodialysis for 6 years: a case report of 3-year-follow-up. BMC Pregnancy Childbirth. 2015;15:218.

28. Jung JH, Kim MJ, Lim HJ, Sung SA, Lee SY, Kim DW, Lee KB, Hwang YH. Successful pregnancy in a patient with autosomal dominant polycystic kidney disease on long-term hemodialysis. J Korean Med Sci. 2014;29:301-4.

29. Thompson S, Marnoch CA, Habib S, Robinson H, Pauly RP. A successful term pregnancy using in-center intensive quotidian hemodialysis. Hemodial Int. 2011;15:S59-63.

\section{Publisher's Note}

Springer Nature remains neutral with regard to jurisdictional claims in published maps and institutional affiliations.

\section{Ready to submit your research? Choose BMC and benefit from:}

- fast, convenient online submission

- thorough peer review by experienced researchers in your field

- rapid publication on acceptance

- support for research data, including large and complex data types

- gold Open Access which fosters wider collaboration and increased citations

- maximum visibility for your research: over $100 \mathrm{M}$ website views per year

At BMC, research is always in progress.

Learn more biomedcentral.com/submissions 